\title{
Sensor Journalism: Pitfalls and Possibilities
}

\section{Amy Schmitz Weiss ${ }^{1}$}

Recibido: 2016-08-25

Enviado a pares: 2016-09-01
Aprobado por pares: 2016-09-14

Aceptado: 2016-09-30

\section{DOI: 10.5294/pacla.2016.19.4.5}

Para citar este artículo / to reference this article / para citar este artigo Schmitz Weiss, A. (2016). Sensor journalism: Pitfalls and possibilities. Palabra Clave, 19(4), 1048-1071. DOI: 10.5294/pacla.2016.19.4.5

\begin{abstract}
The idea of using sensors for journalism is not new, as the practice of doing so has existed for years. However, the application by which they can be implemented for news reporting in a variety of ways at varying costs (from inexpensive to expensive) has created a new realm for the profession. This article identifies the forms in which sensor journalism is currently being practiced and how it may be used in the profession moving forward. A case study of a sensor journalism project is also presented for context. As sensor journalism evolves, it's important to note the pitfalls that one must take into account ranging from sensor manufacturer challenges to user error with the sensor. The implications of this kind of work are discussed in terms of the academy and the profession.
\end{abstract}

\section{Keywords}

Sensors; sensor journalism; future of journalism (Source: Unesco Thesaurus).

1 School of Journalism and Media Studies San Diego State University. Estados Unidos. aschmitz@mail.sdsu.edu 


\section{Periodismo de sensores: dificultades y posibilidades}

\section{Resumen}

La idea de usar sensores para periodismo no es nueva, pues esta práctica ha existido desde hace años. Sin embargo, la aplicación por la cual se pueden implementar para presentar noticias en una variedad de formas a diferentes costos (de económico a costoso) ha creado un nuevo ámbito para la profesión. Este artículo identifica las formas en las que actualmente se practica el periodismo de sensores y cómo se puede usar en la profesión en adelante. También se presenta un estudio de caso de un proyecto de periodismo de sensores para proporcionar un contexto. A medida que evoluciona el periodismo de sensores, es importante señalar las dificultades que se deben tener en cuenta, desde los desafíos del fabricante de sensores hasta los errores del usuario con el sensor. Se discuten las implicaciones de este tipo de trabajo en términos académicos y de la profesión.

\section{Palabras clave}

Sensores; periodismo de sensores; futuro del periodismo (Fuente: Tesauro de la Unesco). 


\section{Jornalismo de sensores: dificuldades e possibilidades}

\section{Resumo}

A ideia de usar sensores para jornalismo não é nova, pois esta prática existe há vários anos. Contudo, a aplicação pela qual se podem implementar para apresentar notícias em uma variedade de formas a diferentes custos (do econômico ao caro) criou um novo âmbito para a profissão. Este artigo identifica as formas em que atualmente se pratica o jornalismo de sensores e como se pode usar na profissão a partir deste momento. Também se apresenta um estudo de caso de um projeto de jornalismo de sensores para proporcionar um contexto. Na medida em que o jornalismo de sensores evolui, é importante destacar as dificuldades que devem ser levadas em conta, desde os desafios do fabricante de sensores até os erros do usuário com o sensor. Discutem-se as implicações deste tipo de trabalho em termos acadêmicos da profissão.

\section{Palavras-chave}

Sensores; jornalismo de sensores; futuro do jornalismo (Fonte: Tesauro da Unesco). 
Today, mobile technology and affordable open-source hardware (e.g. Arduino) have made the possibility of making plug and play sensor kits for environmental monitoring easier than in the past. These kind sof kits have enabled a form of "citizen science" (Ottinger, 2010; Conrad \& Hilchey, 2011; O' Donovan, 2013) to take place in which the public has the opportunity to see for themselves how the environment around them works through measurement of data collected electronically from sensors (e.g. water, soil, air, etc.)

A sensor can be defined as a "device that detects and responds to some type of input from the physical environment. The specific input could be light, heat, motion, moisture, pressure, or any one of a great number of other environmental phenomena. The output is generally a signal that is converted to human-readable display at the sensor location or transmitted electronically over a network for reading or further processing" (Sensor, n.d.).

Using sensors for environmental monitoring is not new and it has been going on for decades in various forms (Ottinger, 2010; Conrad \& Hilchey, 2011; O’ Donovan, 2013; Pitt, 2014). Sensors have been used in the areas of human rights activism, civic accountability and most recently, journalism (Howard, 2013).

In relation to journalism, sensors have been used to investigative stories in a variety of applications for passive use (i.e. consisting of a canister that collects air particles or gases) and/or electronic use (i.e. incorporates a small computer to collect the data).

For example, the Houston Chronicle embarked on a year-long investigation several years ago on air quality in Houston, Texas where people lived near oil refineries and factories. The community participated in the project and used passive sensors to collect data about the air in that vicinity. The reporter discovered poor air quality in the area despite state and federal regulations showing the factories and refineries were within legal limits (Pitt, 2014). 
USA Today launched a series called "Ghost Factories," that examined the soil contaminants left behind in areas where old metal factories used to operate. The reporters used $\mathrm{x}$-ray gun sensors to scan the soil. They visited 13 states and collected soil data from 800 sites. Several sites were above EPA's limits in terms of arsenic and lead (Pitt, 2014).

At WNYC in New York, they used sensors a few years ago to track insects called cicadas. WNYC discovered that cicadas could be predicted based on soil temperature. So, WYNC created an open-source electronic sensor that citizens could use to put in their soil in their own backyards to track the prediction of cicada arrival in the northeast. They collected over 1,700 temperature readings from 800 different locations from the community. Once summer kicked in, another 4,300 reports came in of where the cicadas were. (Pitt, 2014; O’Donovan, 2013)

In 2016 in India, the Hindustan Times launched a project to measure air quality by mapping real-time air quality from monitoring stations across the country and also calibrating air quality data by using low-cost, DIY sensors in Delhi (Wang, 2016).

WNYC embarked on another sensor project in the summer of 2016 by using heat sensors to identify potential health concerns in Harlem apartments. They deployed 60 low-cost electronic sensors to community volunteers and gathered data to see what patterns and trends appeared with the dangers of heat in the Harlem area (Prasad, 2016). They identified that the apartments in Harlem did have higher temperatures than outside during the summer, impacting certain populations such as the elderly who could be exposed to heat-related health issues (Longoria, 2016).

These are just a few examples of how sensors have been used in journalism recently, which have inspired others to embark on similar projects. Journalists and scholars like Matt Waite have identified that the potential of using new, open-source electronic sensors along with solid news reporting techniques can provide new ideas and angles for stories when covering a community (Waite, 2013). 


\section{A Typology}

As noted, sensors in journalism have been used in a variety of situations and the types of sensors have varied as well. Researcher Lily Bui (Bui, 2014) created a typology to categorize sensor journalism projects in all their different shapes and sizes:

- Journalists using sensors - journalists are trained to use a sensor tool, collect and analyze data, report and visualize data from the sensor (Bui, 2014).

- People using sensors - newsrooms ask the public to build sensors or newsrooms provide sensors to the public, and collect their public sensor data for a story (Bui, 2014).

- $\quad$ Existing sensor networks - newsrooms use existing city-level or private company sensor networks to report on a specific issue (i.e. sensor data from toll gates of speeding vehicles) (Bui, 2014).

- Mobile sensing - newsrooms capture data from the public via their smartphones based on the sensors in the device (i.e. GPS, temperature, light, etc.) to capture data for a specific issue/story (Bui, 2014).

- Remote sensing - newsrooms work with organizations and corporations (i.e. NASA, iSeeChange) that have satellite and ground-based sensors to capture data about the climate, weather, air, etc. for a specific story (Bui, 2014).

- Wearables and data donation - newsrooms work with the public, and the data collected from individuals who have wearable devices (i.e. health tracking devices like FitBit) that willingly donate the data collected from their device to a data depository for a possible story. (Bui, 2014)

This sensor journalism typology as Lily Bui states can help us "to examine the work that has been done; tease out emergent patterns; and gain perspective on the field to anticipate its future trajectory" (Bui, 2014).

When examining this typology in the context of today's news industry, sensor journalism projects have mainly been in three areas: 1) journalists 
using sensors to report on a community issue (i.e. Houston Chronicle air quality project), 2) people using sensors by having the public build the sensor and deploy it (i.e. WNYC Cicada Project) and 3) using existing sensor networks to report on what has been found with the sensor data (i.e. part of the Hindustan Times air quality project).

However, sensor journalism projects that incorporate mobile sensing, remote sensing or wearables have yet to be implemented. These kinds of sensor journalism projects may present new forms of how information can be gathered and reported on in a community.

For example, mobile sensing could allow the reporter to be able to deploy a noise project in a community by allowing the public to enable a noise app from within their smartphone and report back the data to the news organization on the noise levels in their community. In aggregate, the reporter could get an idea for time, location and the type of noise level in that community for a potential story.

Another example is remote sensing which entails using sensors from planes, boats, ground-based and/or satellite sensor networks (Bui, 2014). A reporter could potentially embark on a remote sensor project by looking at sea-level rise with satellite sensor imagery in combination with groundbased water sensors.

Lastly, the wearable device is another uncharted area in which a reporter could examine micro data from a volunteer community from their health tracker wearable device to examine an aspect of health or fitness from a particular group for a point in time.

\section{Opportunities for Sensor Journalism}

There are a variety of ways in which sensors can help to provide information for journalists and those sensors have already helped in specific projects aforementioned for organizations like WNYC, Houston Chronicle, USA Today, etc. 
As the development of the Internet of Things (IoT) takes shape in many cities across the globe, the potential for sensors to capture daily interactions and daily activities can also provide unique situations for journalists and possible stories.

\section{Community engagement}

In particular, the creation and deployment of sensors can bring another form of community engagement to the news reporting process. By involving the community in building the sensor, understanding how it works and then allowing them the ability to have the sensor deployed in their own home or backyard, gives a different level of individual empowerment and also creates a unique relationship between the community and the news organization. This kind of community engagement can easily be achieved as demonstrated from the success of the WNYC Cicada project in which they had an overwhelming response for sensors to track bugs. The success in part was in creating a simple sensor, providing easy directions for the install, and providing the public with a data visualization (i.e. map) of the data from all the sensors deployed. Empowering a community on a simple idea and aggregating the involvement can make a difference for the news organization and the journalist who is reporting on the story.

\section{New stories, new angles}

Sensor journalism's potential doesn't come from the sensor technology per say but the data that can be gathered from the sensor in aggregate that can provide insights on an issue or topic not examined previously. The journalist's work in creating and deploying sensors is not the end but just the beginning.

Sensors today whether low-cost or expensive, can provide a variety of data points over a short period or long period of time depending on the project. These data points when gathered among multiple sensors deployed over a specific period of time may be able to show patterns or noting at all. In turn, this can provide insight to the journalist to investigate a different source, angle or altogether a different story based on what the data 
is showing. Sensor data cannot be the answer but the question that drives the journalist to ask why and how, and to dig deeper into the situation.

Sensors may also be able to provide a different kind of dataset to the journalist that can provide a hyperlocal or micro view into a potential issue that previously was only captured at a regional, national or macro level. Again, this may provide insights into a different story angle or source for the story on hand. As much as sensors and their data can help the journalist in the news gathering process, they can also create many challenges for the journalist's work.

\section{Challenges}

The challenges of doing a sensor journalism project can be split into three areas: 1) ethics, 2) education and 3) manufacturer accountability.

From the standpoint of ethics, there are several key questions a journalist must think about before starting a project: Who is going to collect the sensor data? Where will the sensor data be stored? What is the strategy for protecting the identities of those who are collecting the sensor data? What data is the sensor going to collect? How long will the sensors be deployed? How will the sensor data be presented? Each of these questions entails careful thought as to how the sensor is managed and is used.

Another important component of this process is that sensor technology and low-cost, DIY sensors are still somewhat new and unknown to the general public. Providing information on what the sensor is, how it works and what it can and can't do is important. Community members involved in a sensor project have to have information provided to them by the journalist on how the sensor operates and the premise of how the sensor technology will help the greater project. Furthermore, the journalist has an obligation to inform the public on how this sensor technology functions and works other than it just providing data.

Lastly, the sensor technology varies by company and manufacturer. The journalist and the community should know the pitfalls of what sensors 
can and can't do from Manufacturer X or Manufacturer Y. Sensor companies and manufacturers are in the business to sell the sensors - not to manage, create an ethical framework for their use or to quell a community's hysteria when data comes back through the sensor device. Currently, as of the publication of this article, the regulation and vetting of sensor technology by manufacturers is absent and it has created an open and free marketplace for anyone to participate but at the same time, not every sensor is created equal nor will they all operate the same. It's important that the news organization or journalist consider purchasing multiple devices from multiple manufacturers and test them. Also, calibrating the sensor to existing sensors can help make sure that the data captured aligns with a standard from existing sensors.

Throughout the whole process, the journalist needs to be transparent with the community when starting a sensor journalism project. The ethical obligation is paramount.

As opportunities and challenges arise for sensor journalism, experimenting with this kind of innovation is an important step for the journalism profession as sensors become more pervasive in society. The following section details one experiment on how sensor journalism can be done in a community.

\section{An Exploration in Sensor Journalism}

This researcher had an opportunity to embark on a grant-funded sensor journalism project with journalism and science students in spring 2015 in collaboration with a nonprofit news organization. The project focused on air quality in a metropolitan area.

Students were enrolled in the researcher's course in spring 2015 and created open-source electronic air sensors to examine air quality in a metropolitan area (i.e. a population of 1.3 million) and wrote news stories in spring 2015 about the state of air quality in the area. The stories were based on the data collected from the sensors in addition to overall news gathering and reporting on the air quality in the areas where the sensors were deployed. 
The students' news stories were vetted, edited and published by a local nonprofit news organization on their website. A survey was then administered to the news organization's readership about the news coverage. Overall, the study aimed to find out the following:

RQ1: How does the news consumer perceive air quality in this metropolitan area as a result of the news coverage?

RQ2: What is the news consumer's perception of sensors for environmental news?

\section{Method}

An online survey was administered to a group of news consumers between June-July 2015. Three email reminders were sent to increase survey participation. Responses were obtained from 48 participants, a response rate of $4 \%$ based on the nonprofit news organization's newsletter subscriber list of 1,099 individuals that were contacted via email invitation to participate in the study. The response rate may be considered low, but it is an acceptable response rate parameter for online surveys (Sax, Gilmartin \& Bryant 2003). Furthermore, online survey responses can result in lower response rates nowadays as participants face survey fatigue (Dillman, 2007). Survey response rates have also been declining for decades (Dey, 1997; Groves, 1989; Shih \& Fan, 2008; Steeh, 1981; Templeton et al., 1997). Considering this study's purpose of gaining insights from a specific group of readers from a specific local news site and not a national or wider public, the response rate achieved helps to provide validity to the results in this study.

\section{Measurement}

Respondents were asked about their perceptions about air quality, about the news coverage on air quality covered by the students' project, and the sensors used in the project. In addition, respondents were asked to provide demographic information (i.e. age, gender, income, education level and ethnicity). As mentioned previously, respondents were recruited through an email invitation written by the researcher and sent by the news organization to their newsletter subscriber list. 


\section{Operationalization of Variables}

In order to answer the research questions for this study, several questions were asked of the respondents to measure their perceptions of the news coverage of air quality. To answer RQ1, respondents were asked to state the quality of the air in their city currently and after reading the news coverage on it (from very good to poor), to state their level of knowledge about air quality in the city prior to reading the news coverage (from none to a lot), and their perceptions of the state's regulations about air quality. To answer RQ2, respondents were asked their perceptions about air quality sensors before reading the news coverage, their perceptions of air quality sensors as a tool for citizens and reporters, and if the air quality sensors helped them understand the environmental news coverage. The Statistical Package for the Social Sciences (SPSS) V23 was used to analyze collected data. Descriptive and bivariate analyses were run in order to identify significant relationships among the variables.

\section{Sample}

The majority of the sample was female at $63 \%$ in comparison to $37 \%$ male. About $47 \%$ had a college degree, another $47 \%$ had post-graduate training and $5 \%$ stated having some college education. About $42 \%$ were employed full-time, $32 \%$ were retired, $16 \%$ were employed part-time, and $10 \%$ were not employed for pay. As for yearly income level, $40 \%$ said they make over $\$ 100 \mathrm{~K}, 40 \%$ said they make between $\$ 40 \mathrm{~K}-\$ 99 \mathrm{~K}$, and $20 \%$ said they make less than $\$ 40 \mathrm{~K}$ a year.

\section{Results}

RQ1: How does the news consumer perceive air quality in this metropolitan area as a result of the news coverage?

In response to RQ1, the news consumers' perceptions about air quality changed as a result of the news coverage.

About $40 \%$ of respondents $(\mathrm{N}=48)$ said their perceptions of air quality was fair after reading the stories on the news organization's website in comparison to $24 \%$ who said the air quality was good, $16 \%$ who said it was poor, another $16 \%$ had no opinion and $4 \%$ said very good (see Figure 1 ). 


\section{Figure 1. Perception of air quality after reading news coverage}

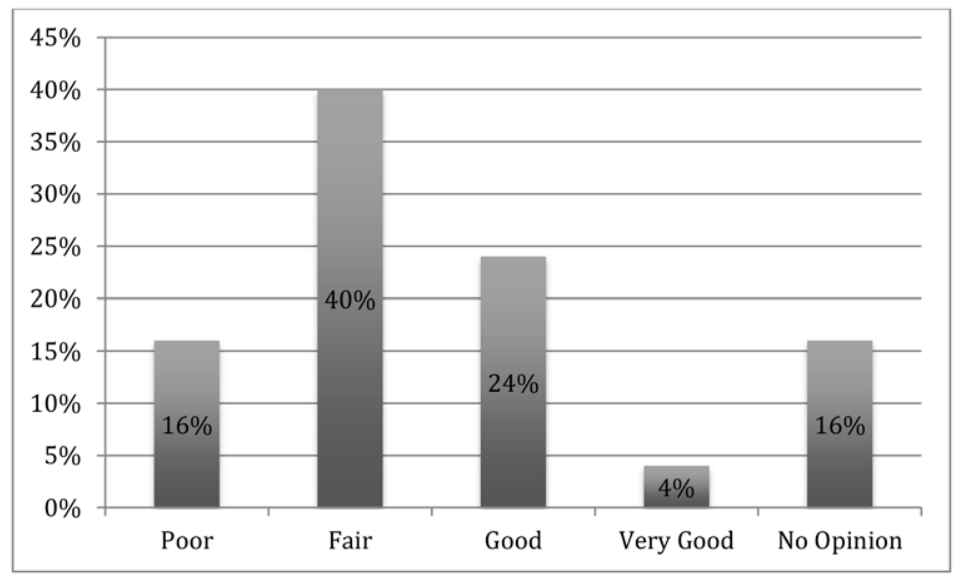

Prior to reading the news coverage, the respondents said they had some knowledge about air quality. About $58 \%$ of respondents $(\mathrm{N}=48)$ said they had some knowledge about air quality in their area in comparison to $7 \%$ who said they knew a lot and $34 \%$ who did not know much or anything at all about it (see Figure 2).

\section{Figure 2. Air quality knowledge prior to reading news coverage}

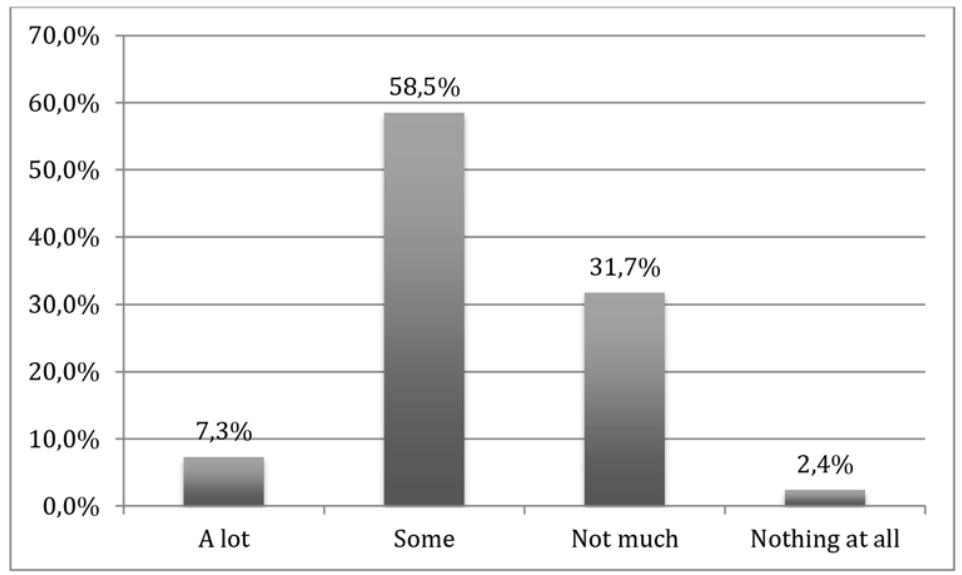


In particular, $84 \%$ of respondents $(\mathrm{N}=25)$ said the use of the sensors in this news coverage helped to explain air quality in comparison to $16 \%$ who didn't think so. Prior to reading the news coverage, $64 \%$ of respondents $(\mathrm{N}=25)$ were aware of air quality sensors in comparison to $36 \%$ that were not.

In a cross-tabulation between these two variables, $81 \%$ who had prior knowledge of air quality sensors did think the sensors used in this project helped to explain air quality in this metropolitan area in comparison to $19 \%$ who did not think it helped explain air quality.

Of those who had no prior knowledge of air quality sensors (89\%) did think the sensors used in this project did explain air quality in this area in comparison to $11 \%$ who did not think it helped explain air quality (see Table 1).

In this case, whether the individual had prior knowledge of sensors or not, the sensors did help to explain the news coverage about air quality.

\section{Table 1}

\section{Prior sensor knowledge and news coverage explained by sensors by percentage}

\begin{tabular}{|c|c|c|}
\hline \multirow{2}{*}{ Sensor News Coverage \% } & \multicolumn{2}{|c|}{ Prior Sensor Knowledge \% } \\
\cline { 2 - 3 } & Yes & No \\
\hline Air quality sensors explained news coverage & 81.3 & 88.9 \\
\hline Air quality sensors didn't explain news coverage & 18.8 & 11.1 \\
\hline N & $(16)$ & $(9)$ \\
\hline
\end{tabular}

Note: Chi-square analysis was run between two variables $\left(x^{2}=.250, d . f=1, p<.617\right)$.

RQ2: What is the news consumer's perception of sensors for environmental news?

In another cross-tabulation between local environmental news consumption and the perceptions of the news coverage using the sensors, despite no significance, $88 \%$ of those who did think the sensors helped to explain news coverage $(\mathrm{N}=20)$ also read local stories about their environment in comparison to $11.8 \%$ who didn't read these stories (See Table 2). 


\section{Table 2}

\section{News coverage explained by sensors and environmental news consumption by percentage}

\begin{tabular}{|c|c|c|}
\hline \multirow{2}{*}{$\begin{array}{c}\text { Environmental News } \\
\text { Consumption \% }\end{array}$} & \multicolumn{2}{|c|}{ Sensor News Coverage \% } \\
\cline { 2 - 3 } & Did Explain Coverage & Didn't Explain Coverage \\
\hline Read local stories about the environment & 88.2 & 100 \\
\hline Don't read stories about about local environment & 11.8 & 0 \\
\hline $\mathrm{N}$ & $(17)$ & $(3)$ \\
\hline
\end{tabular}

Note: Chi-square analysis was run between two variables $\left(x^{2}=2.135, \mathrm{~d} . \mathrm{f}=1, \mathrm{p}<.144\right)$

*Categories were collapsed from monthly, weekly or daily consumption to bivariate.

Those who didn't think the sensors helped to explain news coverage, did read local environmental news. In this case, whether the sensors helped to explain the news coverage or not, the respondents consumed local environmental news.

In relation to local environmental news, in a cross-tabulation between local environmental news interest and the perceptions of news coverage using the sensors, $94 \%$ who stated the sensors helped explain news coverage about air quality were very interested in reading more environmental stories about their area in comparison to $6 \%$ that were not interested. Of those who didn't think the sensors helped explain air quality, $67 \%$ were very interested in more environmental stories in comparison to $33 \%$ who were not interested (see Table 3 ).

\section{Table 3 \\ News coverage explained by sensors and environmental news interest by percentage}

\begin{tabular}{|c|c|c|}
\hline \multirow{2}{*}{$\begin{array}{c}\text { Local Environmental News } \\
\text { Interest in Area \% }\end{array}$} & \multicolumn{2}{|c|}{ Sensor News Coverage \% } \\
\cline { 2 - 3 } & Did Explain Coverage & Didn't Explain Coverage \\
\hline Very Interested & 94.1 & 66.7 \\
\hline Not Interested & 5.9 & 33.3 \\
\hline $\mathrm{N}$ & $(17)$ & $(3)$ \\
\hline
\end{tabular}

Note: Chi-square analysis was run between two variables $\left(x^{2}=2.135, d . f=1, p<.144\right)$ 
In this case, whether respondents stated that the news coverage was explained by the sensor use or not, they still were very interested in environmental news in general.

\section{Additional Findings}

In addition, this study also looked at how data visualization of the sensor data helped the news consumer understand the issue.

A map (see Figure 3) that was published with the news coverage provided specific values for air quality in different neighborhoods where the sensors were deployed. A user could click on a spot on the map, see an image and see air quality data for that neighborhood that were high or low values.

\section{Figure 3. Map of air quality data published on news site}

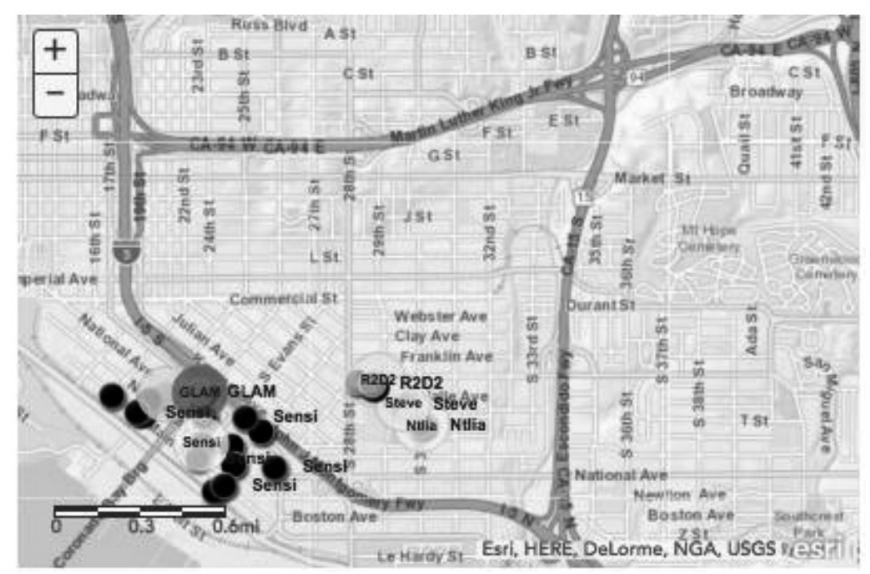

Based on a map (see Figure 3) that had air quality data plotted to specific locations that was published on the news website, respondents stated that this map did help them know more about air quality in the area.

About $65 \%$ of respondents $(\mathrm{N}=48)$ saw the map on the website in comparison to $35 \%$ who had not seen it. Of those that did view the map, $42 \%$ had clicked on the plotted data points to get more information $(\mathrm{N}=12)$ in comparison to $58 \%$ that did not. Ninety-two percent of respondents $(\mathrm{N}=12)$ said they would be interested in seeing more maps related to air 
quality on the news website in comparison to $8 \%$ that were not interested in this feature.

Of those who had viewed the map, $80 \%$ did have prior knowledge of air quality sensors in comparison to $20 \%$ that did not $(\mathrm{N}=15)$ and among those who didn't view the map $(\mathrm{N}=8), 25 \%$ had prior knowledge of sensors in comparison to $75 \%$ who did not.

Those who had viewed the map versus those who didn't also had different perceptions about air quality. Despite no significance, of those who did view the map of air quality data $(\mathrm{N}=23), 33 \%$ stated that they felt the air quality was fair or good after reading the news coverage in comparison to $50 \%$ who did not see the map but thought the air quality was fair. In this case, those who didn't view the map of air quality data had a lower evaluation of air quality than those who did view the map.

In additional analyses, $92 \%$ of respondents $(\mathrm{N}=25)$ said that the sensors could be an informative tool for citizens in comparison to $8 \%$ that didn't. Seventy-nine percent of respondents $(\mathrm{N}=19)$ said they would be willing to have a sensor in their backyard in comparison to $21 \%$ who said no. In this case, respondents overall identified the usefulness and effectiveness of the sensor technology.

\section{Lessons Learned}

In this case study, respondents said that the use of open-source air quality sensors in news coverage did help them understand air quality in their area. Furthermore, the data visualization of the map and its air quality values did aid their learning and understanding of the topic. The respondents in this case study were environmentally-aware as they stated in the survey that they consume these kindsac of stories often and would like to see more local stories about the environment, stories using sensors, and seeing more maps as well on the news website.

This case study shows a snapshot among these respondents of their news experience with this unique topic and it may not be representative of 
the larger population. However, this case study is the first of its kind to explore the use of new, open-source electronic sensors for journalistic purposes and their perceptions of the news coverage accordingly, and it helps to provide a starting point for further research. Future work could include citizen focus groups testing a specific air quality sensor prototype, in-depth interviews with citizens on news coverage of existent sensor journalism work, and experiments testing out different ways in which sensor journalism could be presented via the digital platform.

The implications for this study are two-fold. For the academy, this study explores a new area of inquiry for mass communication research in how open-source sensor technology can be another method by which to examine how news coverage is consumed as well as how perceptions of environmental news may be explored via the digital platform.

For the profession, this study highlights another mode in which news can be explored through the lens of low-cost open-source electronic sensors. As mentioned earlier, news organizations have ventured into this territory (e.g. USA Today, WNYC, etc.) and are in the experimentation stage with this kind of news gathering and reporting with sensor technology. News organizations have the responsibility whether they realize it or not that sensor data can communicate new forms of journalism in a community.

It should be noted that there are some limitations to this study. As this study was highly specialized to a specific set of website readers, the findings may not be representative of the larger population. Second, the news coverage with these sensors was limited to four neighborhoods in the community. With additional neighborhoods, more data and stories could have been done which could have an impact on the overall perceptions from the survey respondents. Also, open-source sensor technology is still in evolution. In the greater scientific community, it is acknowledged that there are issues of calibration, consistency and reliability with this kind of technology. However, it is only through continual trial and error and experimentation that open-source electronic sensors can become a more robust tool. 


\section{Key Takeaways for Journalism Educators}

For journalism educators seeking to deploy a sensor journalism project in their own classroom, there are a few key takeaways.

First, a sensor journalism project can expose students to several learning outcomes: 1) to learn about a new technology and its application in the journalism field; 2) to develop data journalism skills through the lens of how sensors collect data and how that data can later be analyzed and visualized for the public; 3 ) to engage with the community in a project that has immediate and direct results as soon as the sensor is deployed and learn how to maintain those community relationships; and 4) to apply journalistic ethics throughout the project - ranging from ethical questions raised during the sensor build and deployment phase to ethical questions on how to analyze the data and make proper meaning from it. There may be other learning outcomes that an educator will discover in the process, but these are just a few that can be used in a class syllabus. 1

Second, when embarking on a sensor journalism project, it's important to have a solid framework for the project from planning to implementation (Schmitz Weiss, 2015).

\section{Planning}

It's important that the educator has a goal in mind for the project and knows what type of data they want to acquire for a particular issue or question they have in mind. For example, do you want to explore air, water, soil or noise? What particular issues are of immediate concern in the community and how can sensors help to shed light on that issue? This should drive the focus of the project. The sensor market is vast - so once you have identified the issue and the type of data you want to measure, purchase a few sensors by different manufacturers and test them out. As mentioned earlier, beta-testing multiple sensors before deploying them will show how each sensor collects data and what will work best for the project. Not all sensors are made equal or operate the same. Costs for sensors will vary as well so purchasing a few will show the quality of one sensor over another. Educators can visit places online like SparkFun and 
SeeedStudio that sell individual sensors and KitHub that sells sensor kits online for specific projects.

Having collaborators is also important for a sensor project. Consider having multiple departments (i.e. science, computer science, public health, etc.) be a part of the project by involving faculty and students. Identify local nonprofits or community organizations that may want to help with the project through the sensor build or sensor deployment. Lastly, consider partnering with a local news organization to give students the opportunity to work alongside with the pros as they do their reporting, and to have the opportunity to possibly publish the stories they write about from the project.

\section{Implementation}

After the sensor or sensor kit is selected, implementing the project must be carefully done. Identify the locations or places of where the sensor will be deployed, who will be holding onto the sensor, how will the public be involved in the sensor project if at all, and how long will the sensor gather data. These are important questions to answer before deployment. In addition, figuring how to obtain the data from the sensor and where the data will be stored for the short-term and long-term will also need to be determined. Having the students participate in this decision-making process will allow them to see first-hand the kind of decisions that are needed in this kind of endeavor and allows them to feel more ownership of the overall project.

\section{Project conclusion}

Once the sensor data has been collected and the deployment phase is over, collecting the sensors and reviewing the data is another important step. How will the data be cleaned and analyzed? What will be the best ways to visualize the data to make sure it makes sense for the public and the overall story? Does any sensitive sensor data need to be removed from the database and will the dataset be publicly available? Again, having a class discussion about these questions will allow the students to see first-hand all the careful steps they must be considered for this kind of special project. In 
this stage, the data may or may not show big findings for the issue on hand. It will be important that the students embark on their own news gathering and reporting in the community aside from relying on the sensor data to make the overall coverage of the issue comprehensive and robust.

\section{Conclusion and Discussion}

Based on the case study and the examples of journalism sensor projects aforementioned, there are just as many doors of opportunities as there are trap floors that can make the act of sensor journalism happen or fail.

Experimentation is needed to understand the extent of what can be done and its limits. At the same time, it should not come at the risk of the public's safety.

Most sensor journalism projects will fail in some part of the process. It's important that those failures are transparent so the community can understand the progress and outcome. It's also important how the journalist and news organization learns from that failure in the midst of that project that allows its end outcome to be successful. The success might lead to new story idea or angle on a specific issue in a community. The success might lead to a new form of community engagement that didn't exist before. The success might lead to new plans for other sensor projects that could be done in the newsroom. All this is to say is that there is potential for the journalism profession to maximize the possibilities of sensors for unique storytelling where it is appropriate.

However, a cautious path must be charted - as wrong data, incorrect conclusions or analysis of what the sensors collect can hurt versus help the news organization and the trust they have gained with the public. Chaos should not be the outcome of what is reported from the sensors but a fair account of what the sensor collected and how it was vetted with good solid shoe leather reporting. Transparency throughout the sensor project is paramount in these early days of experimentation with the technology.

Journalists and news organizations carry a big responsibility in reporting and telling the stories of their communities - accurately and fairly. 
Using sensors in the news production process is no different - and the responsibility to use it accurately and fairly is on part of the news organization and the journalist.

At the same time, sensors and sensor technology should not be relegated to others to figure out because of the challenges aforementioned - on the contrary, the journalism profession has an obligation to investigate how this technology is and could be used in various contexts and inform the citizenry accordingly. The journalism profession has an opportunity to show how sensors are shaping society and at the same time, be a part of its evolution.

\section{Acknowledgment}

The author would like to thank the Online News Association with support from Excellence and Ethics in Journalism Foundation, the Robert R. McCormick Foundation, the John S. and James L. Knight Foundation, the Democracy Fund, and the Rita Allen Foundation for the 2014-2015 Hack the Curriculum Challenge Grant that funded the air quality collaborative project that was part of this study.

\section{References}

Bui, L. (2014, October 7). A (working) typology of sensor journalism projects. Comparative Media Studies. Retrieved from: http://cmsw. mit.edu/working-typology-sensor-journalism-projects / [Date accessed: May 22, 2016]

Conrad, C. \& Hilchey, K. (2011). A review of citizen science and community-based environmental monitoring: issues and opportunities. Environmental Monitoring and Assessment, 176(1-4), 273-291.

Dey, E. (1997). Working with low survey response rates: The efficacy of weighting adjustments. Research in Higher Education, 38(2), 218-227.

Dillman, D. (2007). Mail and internet surveys. The tailored design method, 2nd ed. NJ: John Wiley \& Sons, Inc. 
Dunwoody, S. (1979). News-gathering behaviors of specialty reporters: A two-level comparison of mass media decision-making. Newspaper Research Journal, 1(1), 29-41.

Groves, R. (1989). Survey errors and survey costs. New York: Wiley.

Howard, A. (2013, March 22). Sensoring the news. Radar. Retrieved from: http://radar.oreilly.com/2013/03/sensor-journalism-data-journalism.html [Date accessed: May 22, 2016]

Longoria, J. (2016, September 8). A century later, city's heat strategies still come up short. WNYC News. Retrieved from: http://www.wnyc. org/story/new-york-summer-heat-death-policy-de-blasio-bloomberg/ [Date accessed: September 12, 2016]

O’Donovan, C. (2013, March 19.) The cicadas are coming: WNYC's tracker is the latest sign of the rise of sensor news networks. Nieman Lab. Retrieved from:http://www.niemanlab.org/2013/03/thecicadas-are-coming-wnycs-tracker-is-the-latest-sign-of-the-riseof-sensor-news-networks

Pitt, F. (2014). Sensors and Journalism. Tow Center for Digital Journalism, A Tow/Knight Report. New York, NY.

Prasad, S. (2016, July 7). This summer, WNYC will investigate New York heat with sensors and volunteers. Poynter.org. Retrieved from: http://www.poynter.org/2016/this-summer-wnyc-will-investigate-new-york-heat-with-sensors-and-volunteers/420397/ [Date accessed: September 12, 2016]

Sax, L., Gilmartin, S., \& Bryant, A. (2003). Assessing response rates and nonresponse bias in web and paper surveys. Research in Higher Education, 44(4), 409-432

Schmitz Weiss, A. (2015, November 5). Remix: How to start teaching sensor journalism. MediaShift. Retrieved from: http://mediashift. 
org/2015/11/remix-how-to-start-teaching-sensor-journalism/ [Date accessed: May 22, 2016]

Sensor. (n.d.). Whatis.com. Retrieved from: http://whatis.techtarget.com/ definition/sensor

Shih T. \& Fan X. (2008). Comparing response rates from web and mail surveys: A meta analysis. Field Methods, 20(3), 249-271.

Steeh, C. (1981). Trends in nonresponse rates. Public Opinion Quarterly, $45,40-57$.

Templeton L., Deehan A., Taylor C., Drummond, C., \& Strang, J. (1997) Surveying general practitioners: Does a low response rate matter? British Journal of General Practice, 47(415), 91-94.

Waite, M. (2013, April 17). How sensor journalism can help us create data, improve our storytelling. Poynter.org. Retrieved from: http:// www.poynter.org/how-tos/digital-strategies/210558/how-sensor-journalism-can-help-us-create-data-improve-our-storytelling/ [Date accessed: May 22, 2016]

Wang, S. (2016, May 18). The Hindustan Times is working to build the definitive online source of real-time air quality in all of India. Nieman Lab. Retrieved from: http://www.niemanlab.org/2016/05/ the-hindustan-times-is-working-to-build-the-definitive-onlinesource-of-real-time-air-quality-in-all-of-india/ [Date accessed: september 12, 2016] 